NBSIR 78-1470

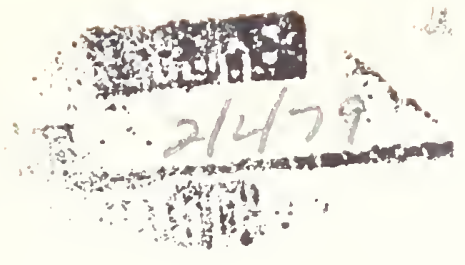

\title{
Examination of Failed Four Inch Diameter Cast Iron Pipe Natural Gas Main, Hamden, Connecticut
}

T. Robert Shives

YISE COPY

H NOT RETOVVE

Fracture and Deformation Division

Center for Materials Science

National Measurement Laboratory

Nationa! Bureau of Standards

Washington, DC 20234

Failure Analysis Report

April 1978

Prepared for

Bureau of Surface Tiansporsation

National Transpcrtation Safesy Bcard

Wasinigtor. DS 20594 
EXAMINATION OF FAILED FOUR

INCH DIAMETER CAST IRON PIPE

NATURAL GAS MAIN, HAMDEN, CONNECTICUT

T. Robert Shives

Fracture and Deformation Division Center for Materials Science

National Measurement Laboratory

National Bureau of Standards

Washington, DC 20234

Failure Analysis Report

April 1978

Prepared for

Bureau of Surface Transportation

National Transportation Safety Board

Washington, DC 20594

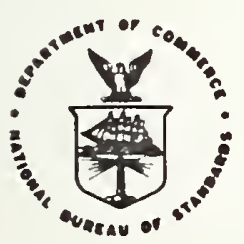

U.S. DEPARTMENT OF COMMERCE, Juanita M. Kreps, Secretary

Dr. Sidney Harman, Under Secretary

Jordan J. Baruch. Assistant Secretary for Science and Technology

NATIONAL BUREAU OF STANDARDS, Ernest Ambler, Director 

1. INTRODUCTION. . . . . . . . . . . . . . . . . . . 1

l.1 Reference. . . . . . . . . . . . . . . . . . 1

1.2 Parts Submitted. . . . . . . . . . . . . . . I

1.3 Background Information ................. . 1

2. PURPOSE. . . . . . . . . . . . . . . . . . . . 1

3. RESULTS OF EXAMINATIONS, ANALYSES, AND TESTS . . . . . . . . 2

3.1 Visual Examination. . . . . . . . . . . . . . 2

3.2 Fractographic Examination ............. 3

3.3 Metallographic Examination. . . . . . . . . . . 3

3.4 Chemical Analysis . . . . . . . . . . . . . 4

3.5 Hardness Measurements . . . . . . . . . . . . 5

3.6 Talbot Tests. . . . . . . . . . . . . . 5

3.7 Ring Tests. . . . . . . . . . . . . . . 6

4. DISCUSSION . . . . . . . . . . . . . . . . 6

5. CONCLUSIONS. . . . . . . . . . . . . . . . . . 7

6. REEERENCES . . . . . . . . . . . . . . . . . 8

7. ACKNOWLEDGEMENT. . . . . . . . . . . . . . . . . . . . 8

\section{FIGURES}

1. The two pieces of four inch cast iron pipe as received at NBS.

2. Fracture surface of the piece of pipe designated $E$ as received at NBS before cleaning.

3. Fracture surface of the piece of pipe designated $w$ as received at NBS.

4. Fracture surface of the piece of pipe designated E after ultrasonic cleaning. 


\section{FIGURES (continued)}

5. The region designated $A$ in figures 2, 3, and 4 at a nigher magnification.

6. Polished transverse section through the piece of pipe designated $E$ about $2 \mathrm{~cm}$ from the fracture.

7. SEM fractograph in the vicinity of $C$, figure 4 .

8. SEM fractograph in the vicinity of D, figure 4.

9. Longitudinal section $C$ near the top of the pipe.

10. Longitudinal section $D$ in about the 10:30 o'clock position when facing the fracture designated $\mathrm{E}$.

11. Longitudinal section $F 2$ at about the $7: 30$ 'clock position when facing the fracture designated $E$.

12. Longitudinal section $F 2$ showing graphitization at the outside of the pipe and along the fracture.

13. Longitudinal section $C$ showing the profile of the unusually flat region of the fracture near the outside of the pipe.

14. Longitudinal section $D$ showing the representative unetched microstructure near the olitside of the pipe.

15. Longitudinal section $D$ showing the representative unetched microstructure at the center of the pipe wall thickness.

16. Longitudinal section D showing the representative unetched microstructure adjacent to the inside of the pipe.

17. Longitudinal section D showing the representative etched microstructure near the center of the pipe wall.

18. Longitudinal section $\$ 2$ showing the etched microstructure adjacent to the fracture and the graphitization at the fracture.

19. Longitudinal section F2 showing etched microstructure adjacent to the inside of the pipe. 
The submitted four inch diameter grey cast iron natural gas main pipe had failed due to a transverse fracture. Failure was probably caused by stresses from an external source. Loading was likely applied in bending. Although there were no fracture features to indicate the fracture origin, it appears likely that the top of the pipe was the last to fail.

Most of the corrosion product on the fracture surface appeared to be superficial. There was one region of significant graphitization at the fracture near the bottom of the pipe. At its deepest, the graphitization had penetrated about one half the pipe wall thickness.

The microstructure, hardness, and chemical composition of the pipe material appeared to be satisfactory. The material satisfied the Talbot test and ring test requirements of American National standard A21.9, 1970. 
Examination of Failed Four Inch Diameter Cast Iron Pipe Natural Gas Main, Hamden, Connecticut

\section{INTRODUCTION}

\subsection{Reference}

National Transportation Safety Board, Washington, DC 20594. This investigation was conducted at the request of Mr. Richard G. Marini, Pipeline Safety Specialist, National Transportation Safety Board (NTSB). The requesting letter was dated October 31, 1977.

\subsection{Parts Submitted}

Two pieces of the failed four inch diameter cast iron pipe were submitted to the National Bureau of standards for examination. The nominal wall thickness of the pipe was $3 / 8$ inch. Each piece of pipe contained one of the two mating fracture faces. The two pieces of pipe, designated $\mathrm{E}$ and $\mathrm{W}$ before being received at NBS, measured approximately 30 and $30.5 \mathrm{~cm}$, respectively, in length. The fracture surface from the piece labeled $E$ was used for most of this examination. The fracture surface from the piece labeled $W$ was not cleaned or sectioned, although the piece of pipe itself was cut in order to machine specimens for Talbot tests. Both pieces were marked before being submitted to NBS to indicate the top of the pipe as it had been oriented in service. The parts are shown in figure $I$ as they were received at NBS.

\subsection{Background Information}

The information in this section was supplied by the National Transportation Safety Board. Failure of the pipeline occurred in a grassy area adjacent to an apartment complex in Hamden, Connecticut. The grassy area was subject to pedestrian traffic only. The break was detected during an investigation after an explosion in a building. There were about $415 / 8$ inches of ground cover. At the point of the break, the pipeline was running parallel to and about two feet from the outside wall of the apartment complex. The break was well removed from the paved street. The pipeline was installed in 1953. Normal operating pressure was 0.25 psig.

\section{PURPOSE}

The National Transportation Safety Board requested that the National Bureau of Standards examine the submitted failed pipe and perform a visual examination, chemical analysis, metallographic examination, determination of graphitization, determination of fracture origin, Talbot tests, ring tests, hardness and microstructure characterization. 


\section{RESULTS OF EXAMINATIONS, ANALYSES, AND TESTS}

\subsection{Visual Examination}

The submitted pipe had fractured transversely. The outside surface of the pipe had been cleaned for a length of about $10 \mathrm{~cm}$ on either side of the fracture at what was reported to be the top of the pipe as it had been oriented in service. Beyond the cleaned regions, the pipe was covered with fairly tightly adhering soil and surface scale (corrosion product). The surfaces of the pipe pieces near the ends opposite those containing the fractures had been partially cleaned. In these regions, one of the pipe pieces had been marked $E$ and the other had been marked $W$. The top of the pipe is shown in figure 1 as it was received at NBS. The two mating fracture surfaces are shown as received at NBS in figures 2 and 3 . The top of the pipe as it lay in the ground is at the top of the photographs in both figures. Both fracture surfaces were covered with corrosion product. There were two regions of special interest in mating locations on the two fracture surfaces. One of these regions is near the top of the pipe and is indicated by bracket $A$ in figures 2, 3, and 4. This region is adjacent to the outside surface of the pipe and, at its thickest point, penetrates about $2 / 3$ of the pipe wall thickness. The fracture was smoother in this region than elsewhere, and the corrosion product had a duller appearance than elsewhere. There is a small apparent shear lip at the outside of the fracture face within bracket $A$ in figure 3 . This feature appears as a depression on the fracture face shown in figures 2 and 4.

The second region of interest is near the bottom of the pipe as the pipe was oriented in service. This region is indicated by bracket $B$ in figures 2,3 and 4 . As in region $A$, the area of interest is adjacent to the outside surface of the pipe. On the as-received (uncleaned) fracture surfaces, the region appeared to have been graphitized.

The fracture surface from the piece of pipe marked $E$ was cleaned with detergent in an ultrasonic cleaner. Most of the corrosion product was removed during the cleaning process in a relatively short time indicating that most of the corrosion product was essentially superficial. The cleaned fracture surface is shown in figure 4. The region designated $A$ in figures 2,3 and 4 revealed a number of small shiny areas indicating possible mechanical damage. Region $A$ is shown in figure 5 at a higher magnification than in previous figures. The mechanical damage could have occurred from the mating fractures rubbing together.

After the fracture surface was cleaned, it was determined that there was indeed significant graphitization in region B. No other regions of significant graphitization were detected on the fracture surface. 
A transverse section was taken through the piece of pipe designated $E$ about $2 \mathrm{~cm}$ from the fracture. This section is shown in figure 6 after it had been polished. There was one region of significant graphitization near the bottom of the pipe (arrow, figure 6). This region corresponds to the location of the graphitization at the fracture surface. There was some minor graphitization in a few other locations around the section. In every case, the graphitization was adjacent to the outside of the pipe.

\subsection{Fractographic Examination with the SEM}

Three regions of the fracture surface were examined with the scanning electron microscope (SEM) after ultrasonic cleaning. These regions are in the vicinity of $C, D$, and $F$ indicated in figure 4. There was still some corrosion product on the surface in all three areas, but where the corrosion product did not mask the fracture features, cleavage was the dominant fracture mode. Cleavage indicates a very low ductility or brittle fracture. Brittle fracture is expected in cast iron.

More corrosion product remained on the fracture surface in region $A$ (figures 2, 3 and 4) than in the other regions examined. An SEM fractograph from region $A$ is shown in figure 7. A considerable amount of corrosion product is evident, but there is also evidence of cleavage.

An SEM fractograph from a region less affected by corrosion product (near D, figure 4) is shown in figure 8. Cleavage is again the dominant mode.

In the vicinity of the graphitized region ( $F$, figure 4 ), cleavage is the dominant fracture mode where the fracture surface is not covered with graphitized product.

\subsection{Metallographic Examination}

Longitudinal sections intersecting the fracture were taken at the locations indicated in figure 4. One each was taken at locations $C$, $D, F 1, F 2$, and F3. The fracture profile at locations $C, D$, and $F 2$ is shown in figures 9, 10, and 11, respectively. A small amount of graphitization and some other corrosion product (rust) can be seen on the outer surface of section $C$, but there is no evidence of graphitization on the fracture surface itself. In section $D$, somewhat more graphitization can be seen on the outside surface of the pipe in the vicinity of the fracture. The deepest penetration of the graphitization in this section is about $15 \%$ of the wall thickness. No graphitization is evident on the fracture itself.

In section F2, figures 11 and 12, more graphitization was evident than in either sections C or D. An inward growing "spike" or graphitization near the left of the figure had penetrated about $40 \%$ of the pipe wall thickness. Graphitization was found on the fracture surface for about the 
outer half of the pipe wall thickness. Part of the fracture profile of section F2 showing some of the graphitization on the outer wall surface and on the fracture is shown in figure 12. The graphitization in sections $F 1$ and $F 3$ was very similar to that in section $F 2$.

The fracture profile of section $C$ adjacent to the outside of the pipe is shown in figure 13 at a higher magnification than in figure 9 . The fracture is quite flat and relatively smooth in this region, which is about 15\% of the wall thickness at this section.

The microstructure of the cast iron varied across the wall thickness of the pipe. Unetched-as polished-fields from section D considered to be representative of the microstructure adjacent to the outside, in the center, and adjacent to the inside of the pipe are shown in figures 14 , 15, and 16, respectively. The graphite flakes in the three regions can be classified as follows:l

$\begin{array}{ll}\text { Outside } & \text { mostly type A } \\ \text { Center } & \text { mostly type } B \text { with some type E } \\ \text { Inside } & \text { mixture of types A and B }\end{array}$

An etched field from section $D$ at the center of the wall thickness is shown in figure 17. (Note: This figure is at a higher magnification than the previous figures.) In addition to the graphite flakes, the microstructure consists of pearlite (grey-fingerprint pattern) and ferrite (light colored phase).

An etched field from section $F 2$ showing graphitization along the Eracture appears in figure 18. The graphitization is at the right. The microstructure of the material that has not been graphitized consists again of graphite flakes, pearlite, and ferrite; but there is much less pearlite evident here than in figure 17.

There was a layer adjacent to both the inside and outside surfaces of the pipe that had a higher concentration of pearlite than the rest of the material. Figure 19 shows this layer at the inside of the pipe.

\subsection{Chemical Analysis}

A sample of the cast iron pipe material was submitted to a commercial laboratory for chemical analysis. The results of that analysis are as follows:

\section{Element}

Total carbon

Combined carbon

Manganese

Phosphorus

Sulfur

Silicon

Nickel

Chromium

Molybdenum

Copper

\section{Weight Percent}
3.66
0.38
0.37
0.60
0.083
I. 70
0.02
0.05
$<0.01$
0.18 
The chemical composition of the material meets the requirements set forth in American National Standard A2I.9, Cast-Iron Pipe Centrifugally Cast in Sand-lined Molds for Gas, 1970 edition. These requirements are as follows:

Element

Phosphorus

Sulfur

\section{Percent, maximum}

0.90

0.12

\subsection{Hardness Measurements}

Hardness measurements were made on the transverse section shown in figure 6 (after the photograph was taken). Two attempts were made to make Brinell hardness measurements, but in each case, the indentor cracked the cast iron. Therefore, Rockwell B (HRB) hardness measurements were made. The average for five measurements was HRB 79 and the range was HRB 76-81. A hardness of HRB 79 is approximately equivalent to a Brinell hardness of 147. The Brinell hardness of grey cast iron may range from about 140 to $200^{2}$.

\subsection{Talbot Tests}

Talbot tests were performed on three specimens machined from the piece of pipe designated $W$ after a transverse section containing the fracture had been removed so that the fracture could be preserved. The tests were conducted in accordance with American National Standard A21.9.

From the results of the Talbot tests, the modulus of rupture and the secant modulus of elasticity were calculated according to the following formulae as given in American National Standard A21.9.

$$
\begin{aligned}
& R=\frac{10 W}{t d^{2}} \\
& E_{3}=\frac{2 I \cdot 3 R}{d y}
\end{aligned}
$$

where $R$ = modulus of rupture, psi

$W=$ breaking load, lbs

$t=$ width of Talbot strip (pipe wall thickness), inches

$\mathrm{d}=$ depth of strip, in (intended to be 0.50 )

$E_{3}=$ secant modulus of elasticity, psi

$y=$ deflection of the strip at the center at the breaking load, inches

The calculated modulus of rupture and the secant modulus of elasticity for the three specimens are as follows:

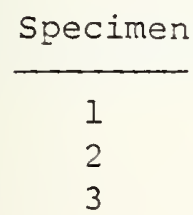

$$
\begin{aligned}
& \text { R, psi } \\
& \hline 51,900 \\
& 49,000 \\
& 50,900
\end{aligned}
$$

$\frac{E_{3}, p s i}{10,800,000}$
$11,400,000$
$10,500,000$ 
The standard calls for a minimum of 40,000 psi for the modulus of rupture. The secant modulus of elasticity must not exceed 250 times the actual value of the modulus of rupture for pipe cast in sand-lined molds. All three specimens met the requirements for both the modulus of rupture and the secant modulus of elasticity.

\subsection{Ring Tests}

Ring tests were performed on three specimens machined from the piece of pipe designated $\mathrm{E}$ in accordance with American National Standard A21.9. Because of the limited amount of material available for testing, the length of the ring test specimens was nominally three inches.

The modulus of rupture was calculated from the results of the ring tests according to the following formula given in American National Standard A21.9:

$$
R=0.954 \frac{W(d+t)}{b t^{2}}
$$

where $\mathrm{R}=$ modulus of rupture, psi

$W=$ breaking load, lbs

$\mathrm{d}=$ average inside diameter of the ring, inches

$t=$ average thickness of metal along the line of fracture, inches

$b=$ length of the ring, inches

The modulus of rupture as calculated from the ring test data is as follows:

\begin{tabular}{cc} 
Specimen & R, psi \\
\hline 1 & 61,600 \\
2 & 59,900 \\
3 & 59,900
\end{tabular}

The standard calls for a minimum of 40,000 psi for the modulus of rupture as calculated from the results of the ring test. All three specimens met this requirement.

\section{DISCUSSION}

This four inch diameter grey cast iron natural gas main pipe failed due to the initiation and propagation of a transverse crack. At the fracture, there was one region of significant graphitization near the bottom of the pipe as it had been oriented in service. The graphitization extended through about one half the pipe wall thickness in this region. As would be expected, the graphitization initiated at the outside of the pipe. The fracture exhibited very little if any ductility as is characteristic of cast iron fractures. 
The fracture origin could not be definitely established from the features on the fracture surface. It does, however, appear that the last part of the fracture to form may have been at the top of the pipe as suggested by the slight lip on the outside of the fracture at the top. It is not clear why the fracture appearance at the top is different from the appearance of the rest of the fracture. If, indeed, the top was the last to fail, then the origin of the fracture should be well removed from the top and may have been at the region of graphitization near the bottom of the pipe. Failure appears to have been caused by an external force probably applied in bending.

The chemical composition, modulus of rupture as calculated from both the ring tests and the Talbot tests, and the secant modulus of elasticity as calculated from the Talbot tests all met the requirements set forth in ANSI 21.9.

The hardness is within the acceptable range for grey cast iron. There was considerable variation in the microstructure of the material across the wall thickness of the pipe. This variation was probably due to the casting procedure employed and differences in the cooling rate across the wall thickness. The microstructure appears to be satisfactory.

\section{CONCLUSIONS}

1. This failed grey cast iron natural gas main pipe fractured transversely apparently due to loading from an external source probably applied in bending.

2. Most of the corrosion product on the fracture surface appeared to be superficial.

3. The location of the fracture origin was not established.

4. There was one region of significant graphitization at the fracture near the bottom of the pipe as it was oriented in service. The graphitization penetrated about one half the pipe wall thickness at the point of deepest penetration.

5. The frâcture mode was primarily cleavage.

6. The chemical composition of the material appeared to be satisfactory within the limits of ANSI Standard A2l.9.

7. The microstructure of the material appeared to be satisfactory.

8. The hardness of the material appeared to be satisfactory.

9. The calculated modulus of rupture and secant modulus of elasticity met the requirements of ANSI Standard A21.9. 


\section{REFERENCES}

1. Metals Handbook, 8th Edition, American Society for Metals, Vol. 7 , 1972, p. 82 .

2. Charles F. Walton, Editor, Gray and Ductile Iron Castings

Handbook, Gray and Ductile Iron Founders' Society, Inc., 1971.

\section{ACKNOWLEDGEMENT}

Mr. Leonard C. Smith of the NBS Fracture and Deformation Division assisted in this investigation. He performed the hardness measurements, the metallographic specimen preparation, the photographic work, and he assisted with the ralbot and ring tests. 


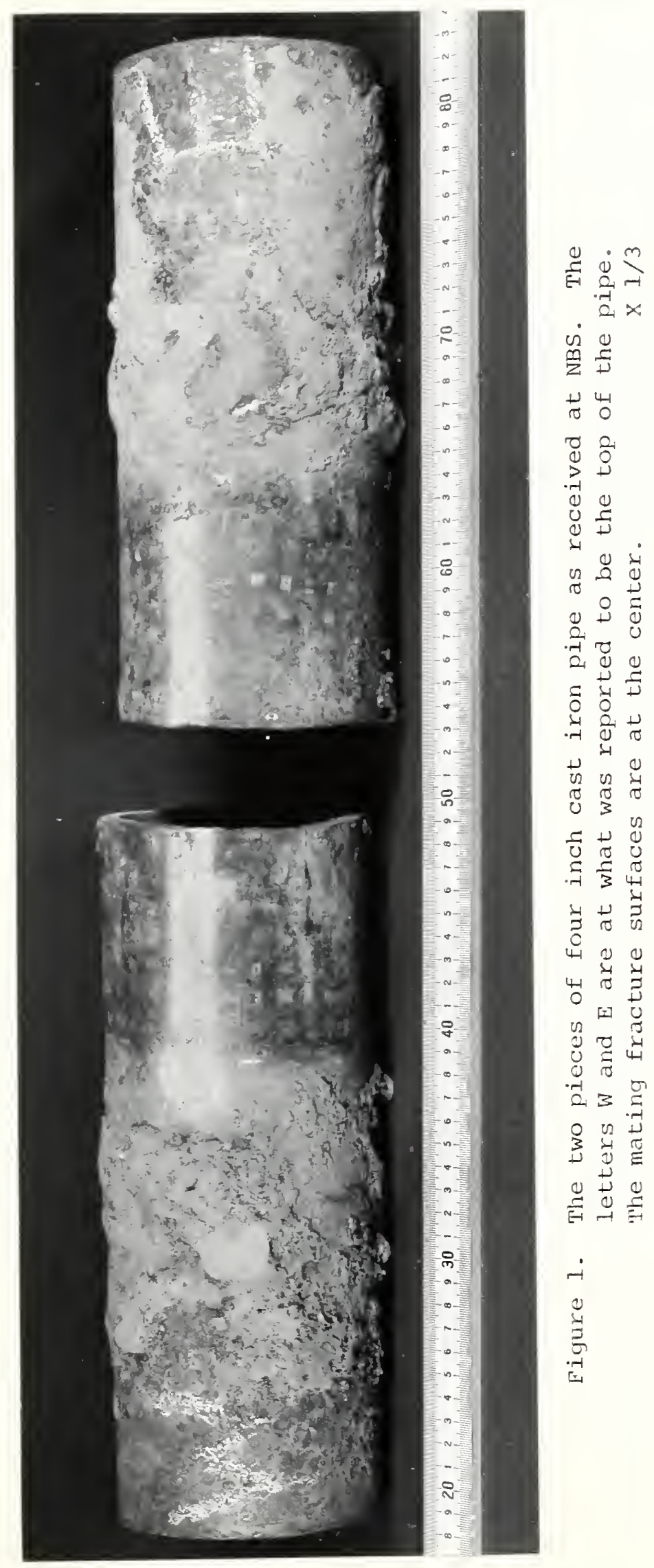




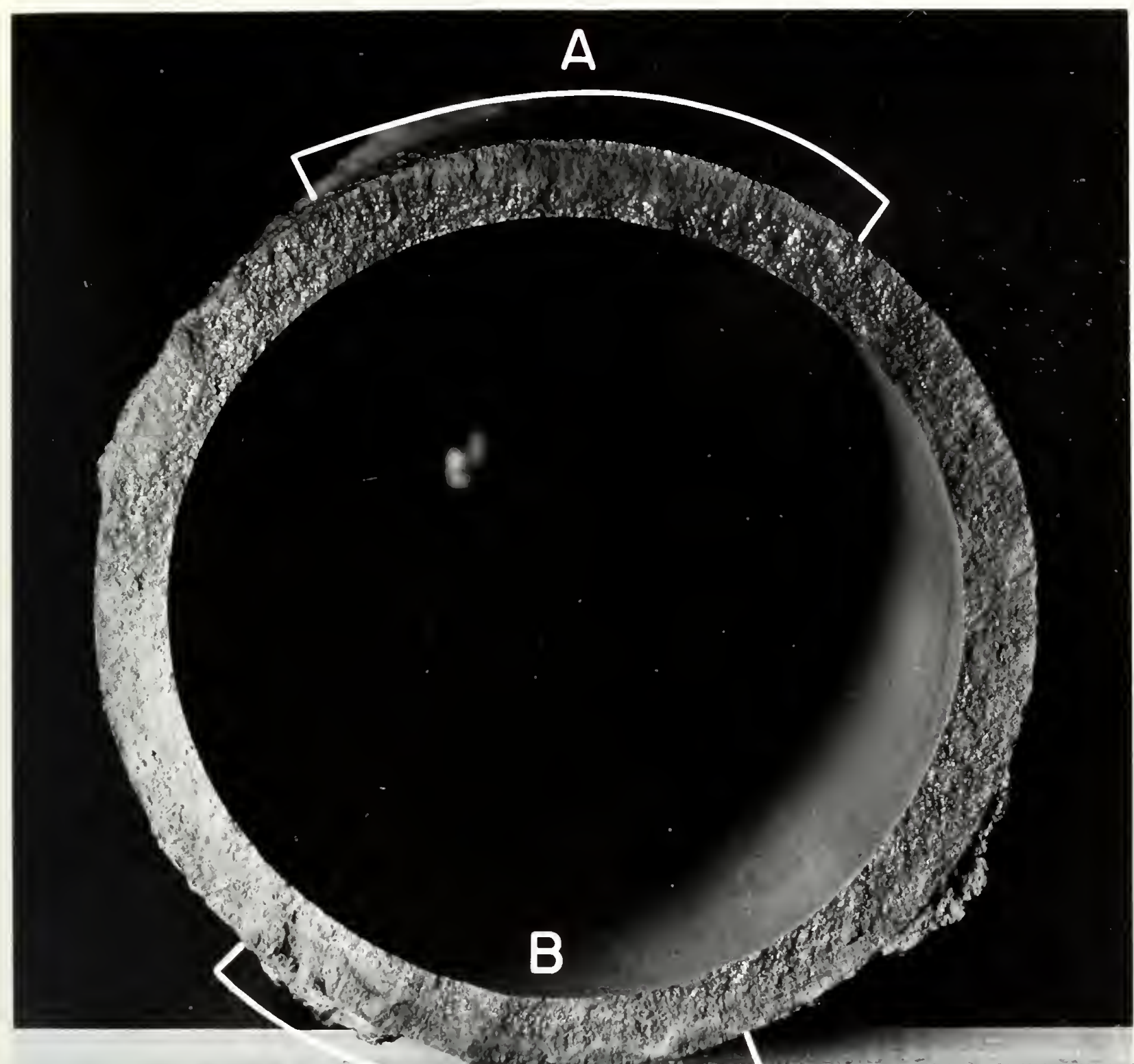

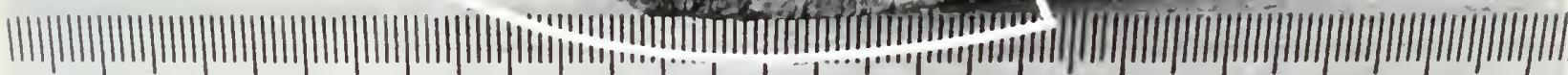

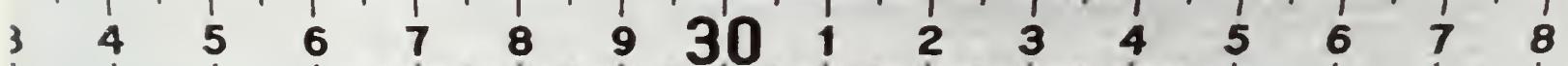

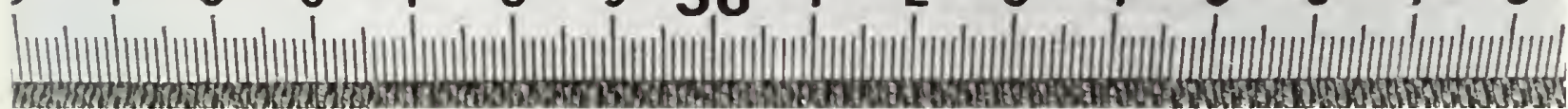

Figure 2. Fracture surface of the piece of pipe designated $E$ as received at NBS before cleaning. Regions designated $A$ and $B$ are of special interest and are discussed in the text of the report. The top of the pipe as it lay in the ground is at the top in the figure. $\mathrm{x}$ I 



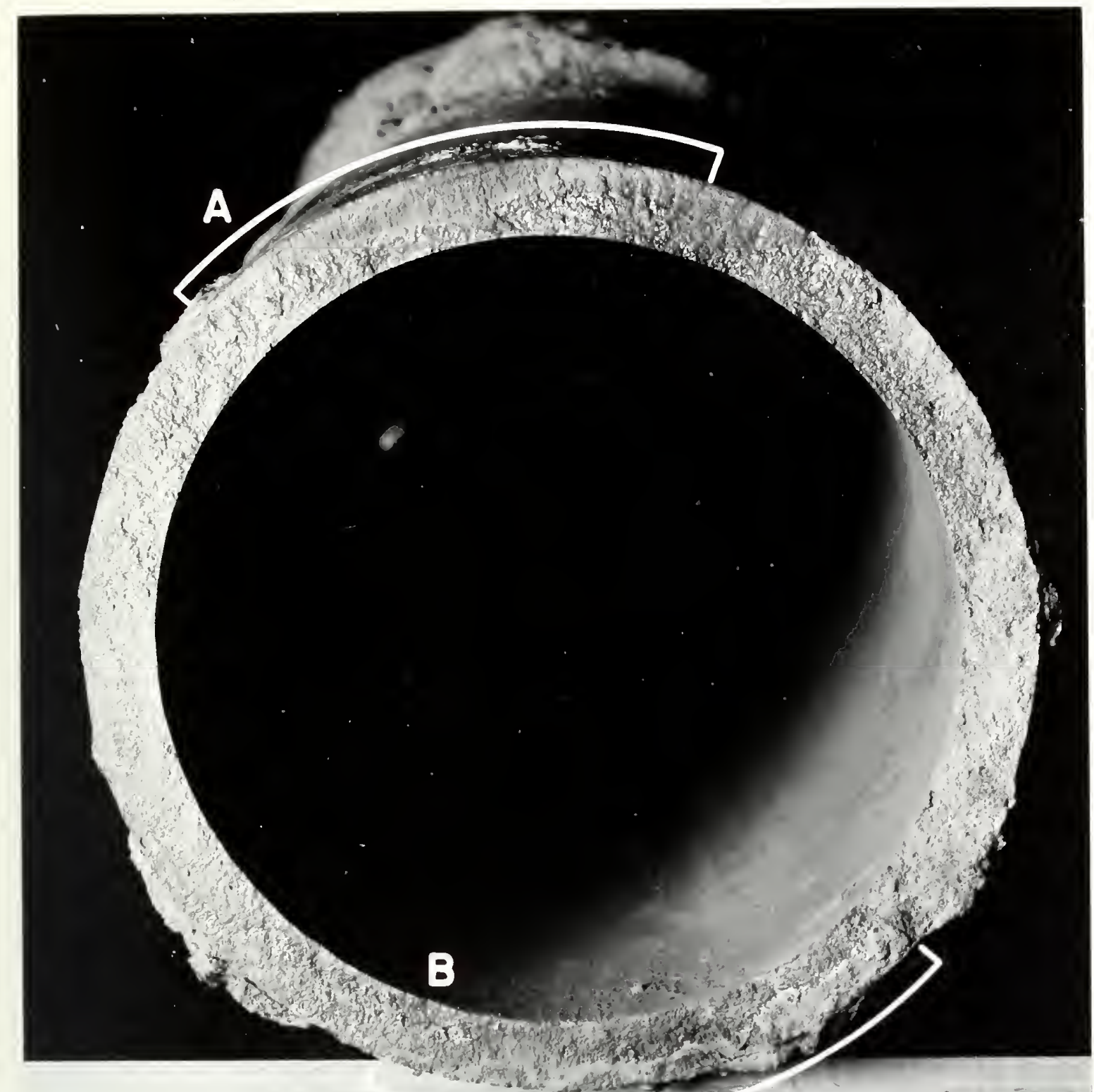

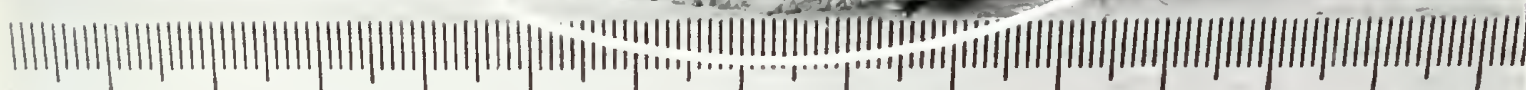

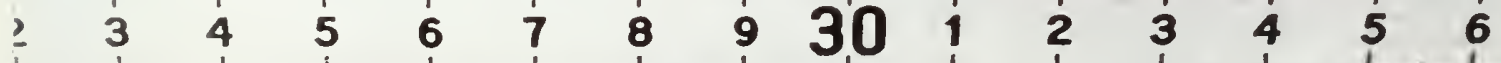

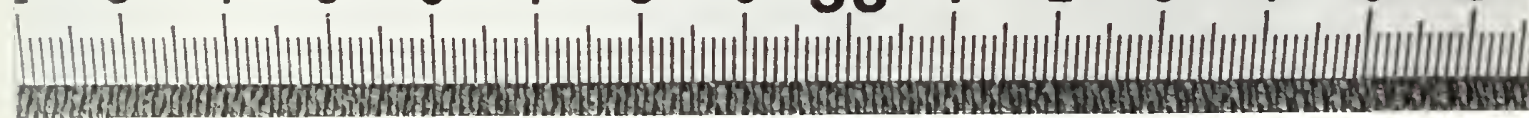

Figure 3. Fracture surface of the piece of pipe designated $W$ as received at NBS. Regions designated $A$ and $B$ are in the mating locations to the similarly designated regions in figure 2. The top of the pipe as it lay in the ground is at the top in the figure. 



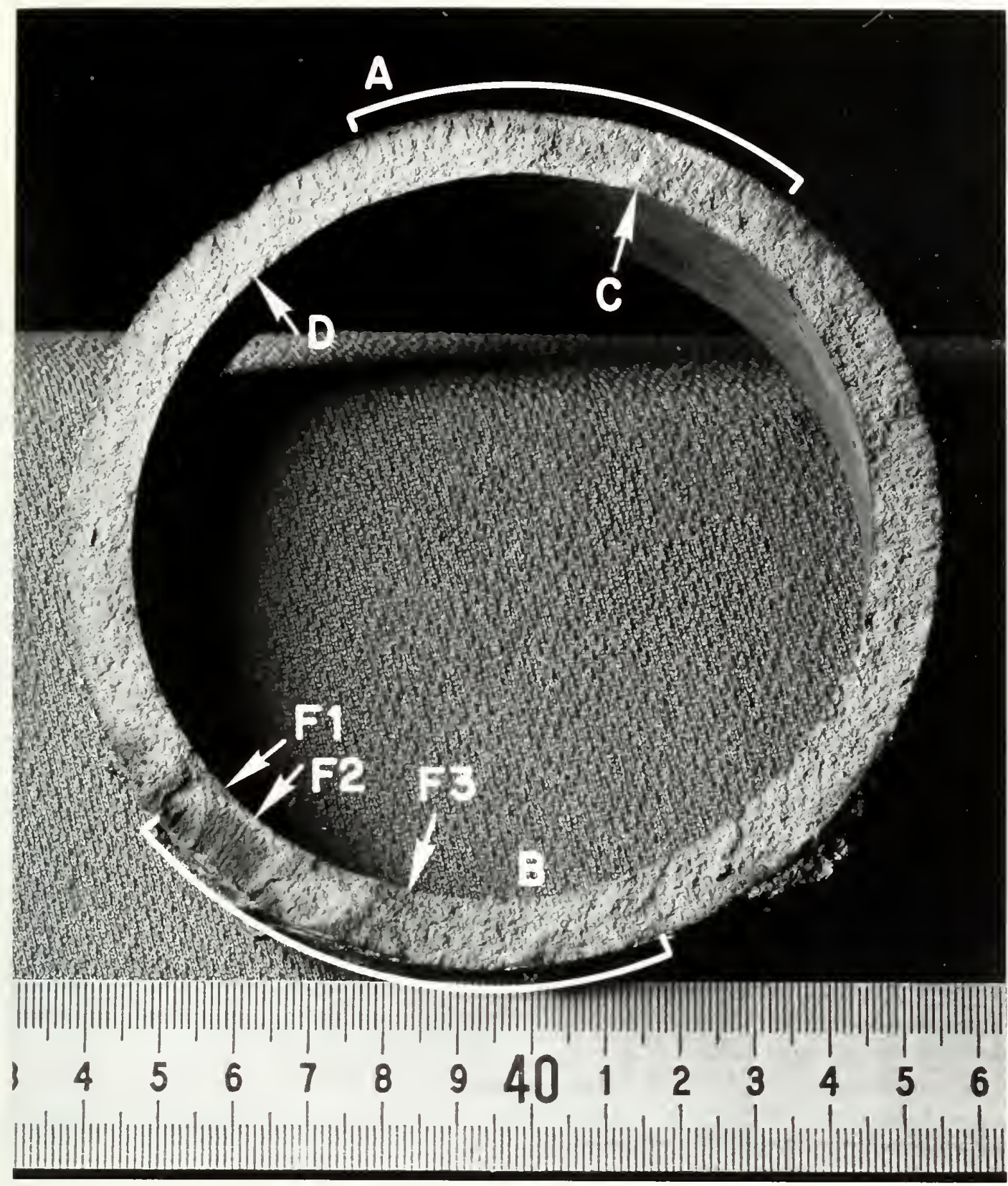

Figure 4. Fracture surface of the piece of pipe designated E after ultrasonic cleaning. The region labeled $\mathrm{A}$ has suffered apparent mechanical damage. The region labeled $B$ exhibits graphitization. Arrows C, D, FI, F2, and F3 indicate the locations where sections were taken for metallographic examination. 


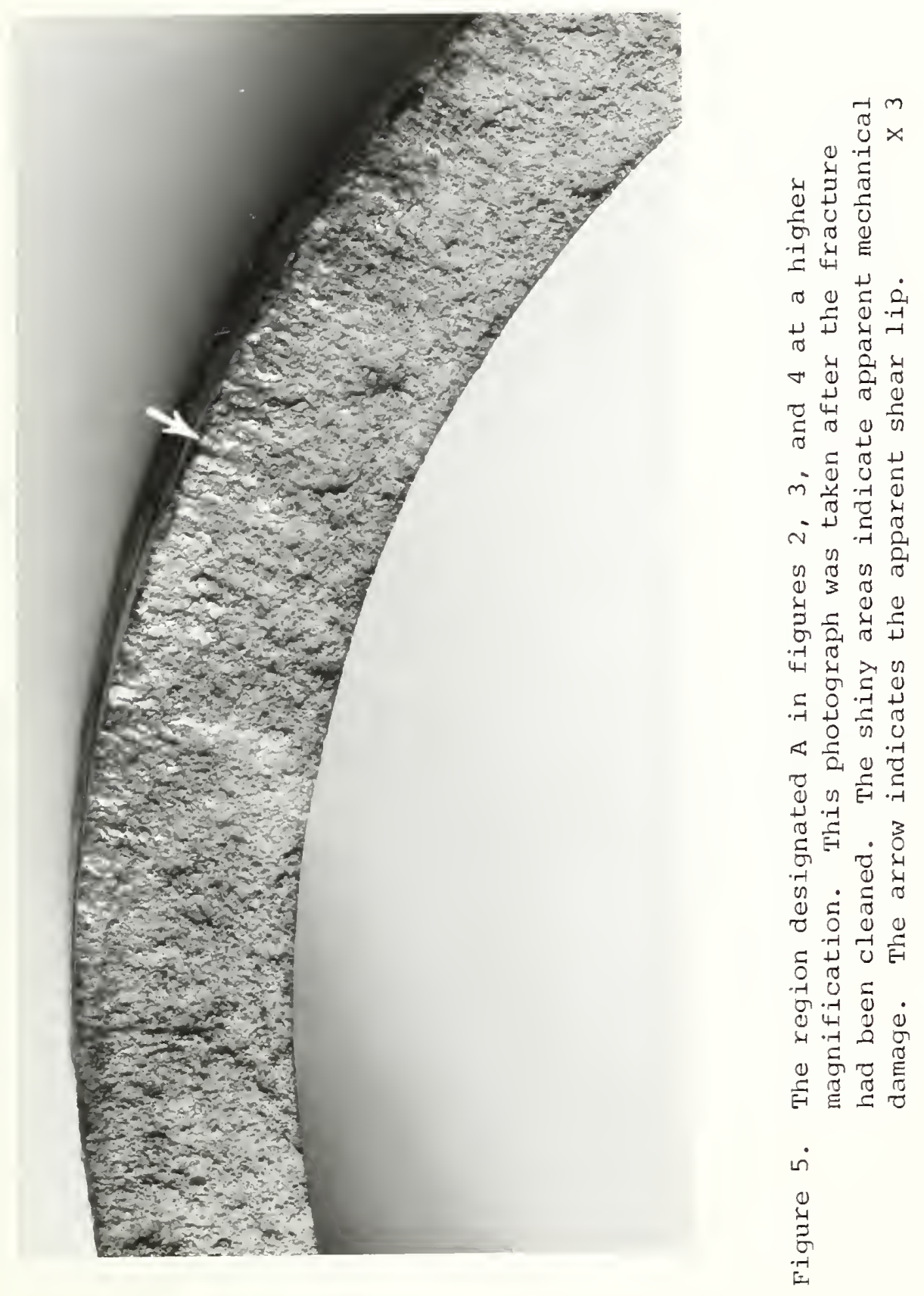




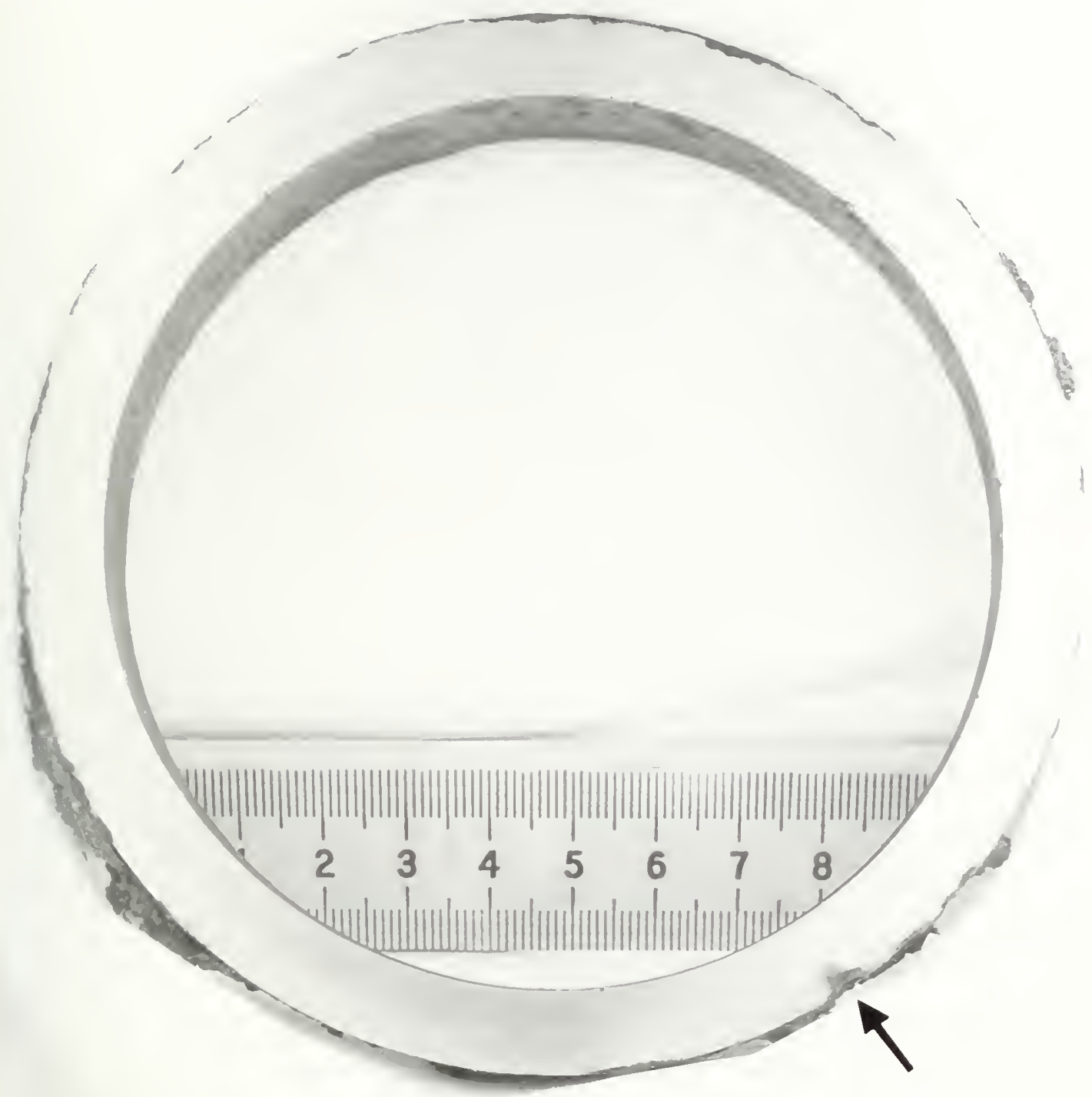

Figure 6. Polished transverse section through the piece of pipe designated $\mathrm{E}$ about $2 \mathrm{~cm}$ from the fracture. One region of significant graphitization is indicated by the arrow. Minor graphitization is evident in other regions of the section. As polished 


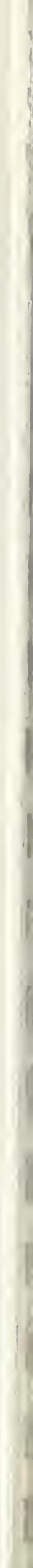




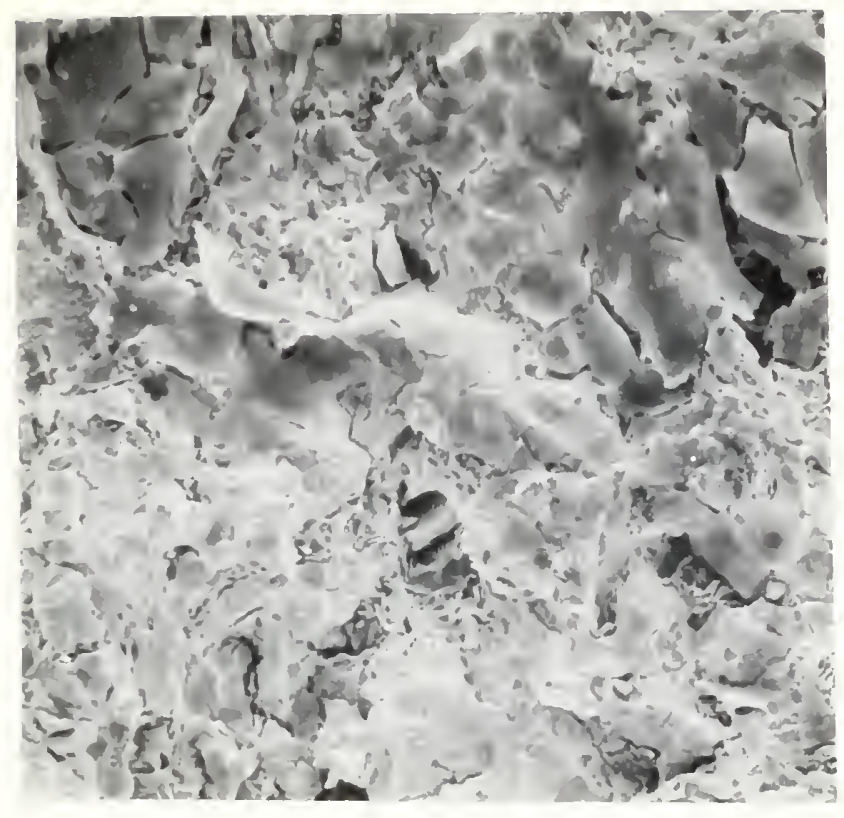

Figure 7. SEM fractograph in the vicinity of C, figure 4. A considerable arount of apparent corrosion product is evident. The predominant mode of fracture is cleavage. $\quad$ X 525

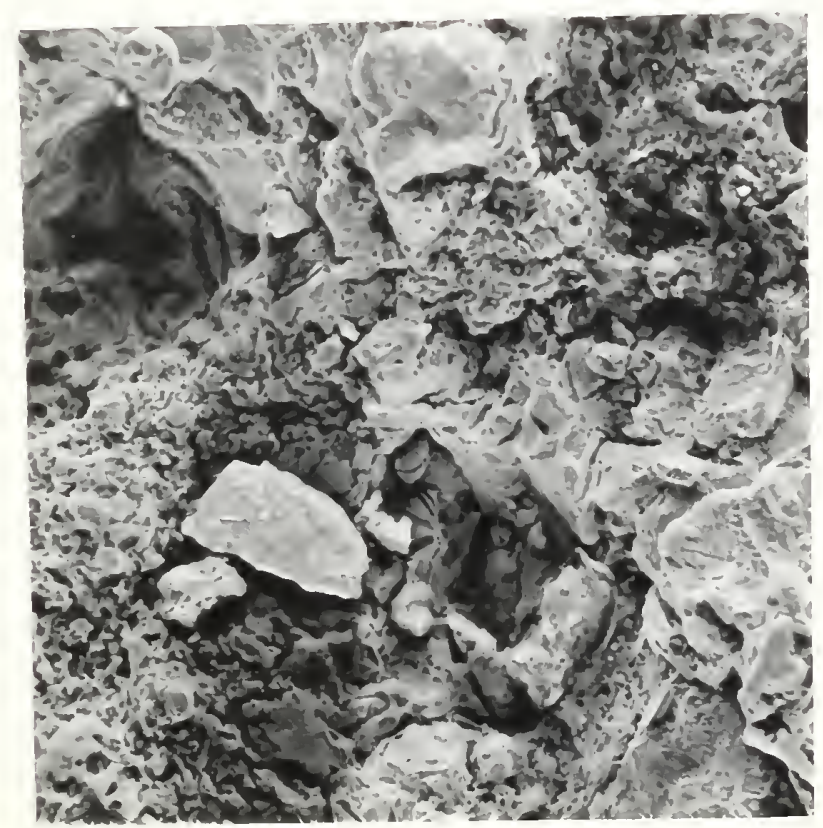

Figure 8. SEM fractograph in the vicinity of $D$, figure 4, exhibiting cleavage as the predominant mode of fracture. 


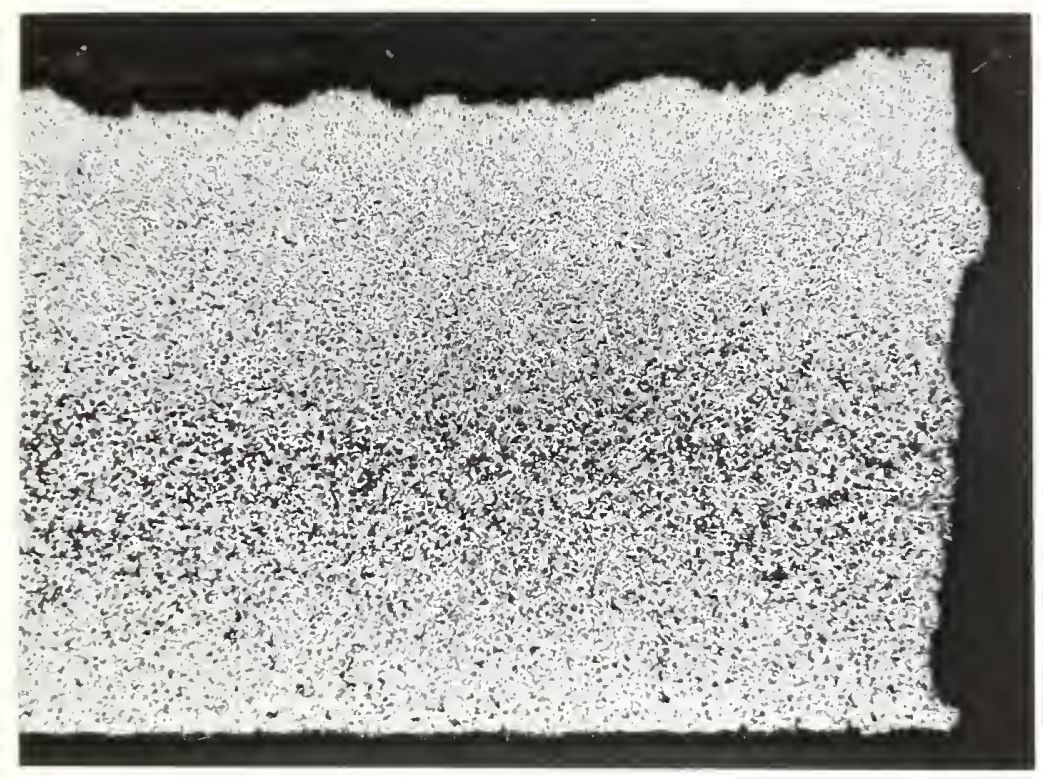

Figure 9. Longitudinal section $C$ near the top of the pipe. The outside of the pipe is horizontal at the top, the inside is horizontal at the bottom. The fracture profile is vertical at the right. A small amount of graphitization is evident at the outside surface.

As polished

X $71 / 2$

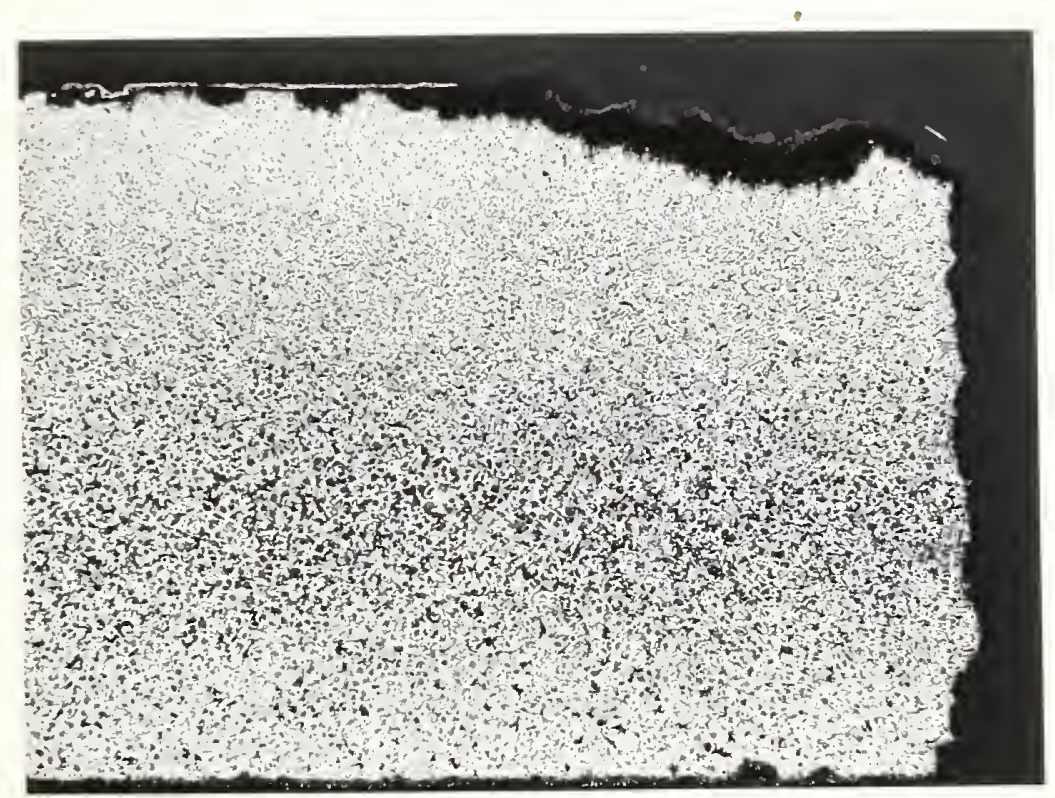

Figure 10. Longitudinal section D in about the 10:30 ' clock position when facing the fracture designated $E$. The outside of the pipe is horizontal at the top, the inside is horizontal at the bottom. The fracture profile is vertical at the right. Somewhat more graphitization is evident in this section than in the one shown in figure 7.

As polished 


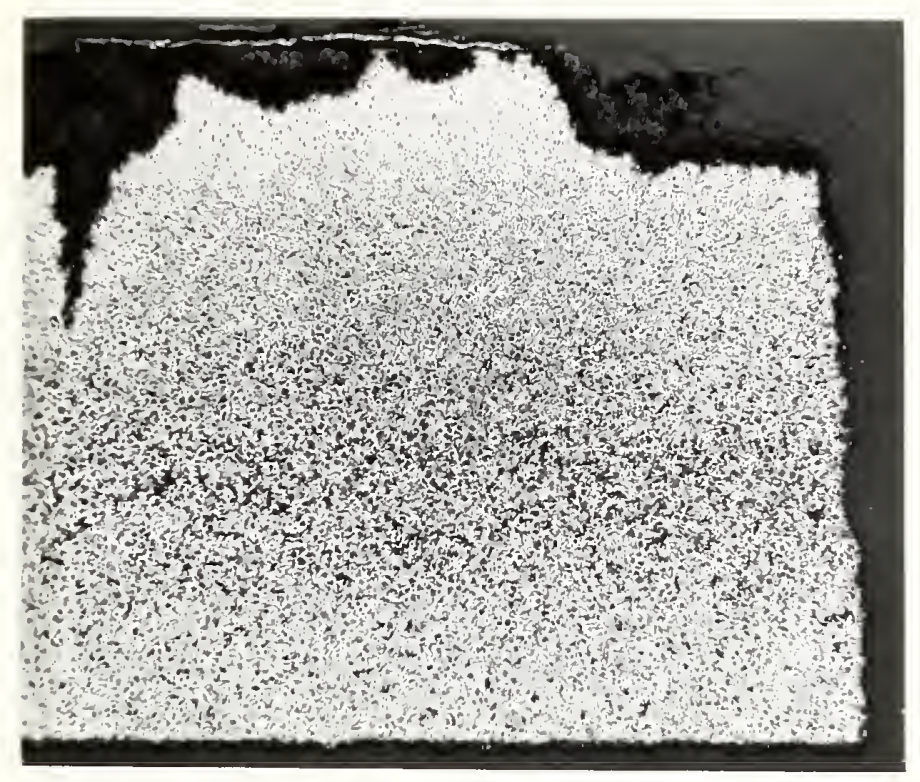

Figure 11. Longitudinal section F2 at about the 7:30 $0^{\prime c l o c k}$ position when facing the fracture designated $E$. The outside of the pipe is horizontal at the top, the inside is horizontal at the bottom. The fracture profile is vertical at the right. A considerable amount of graphitization is evident.

As polished

$\times 71 / 2$

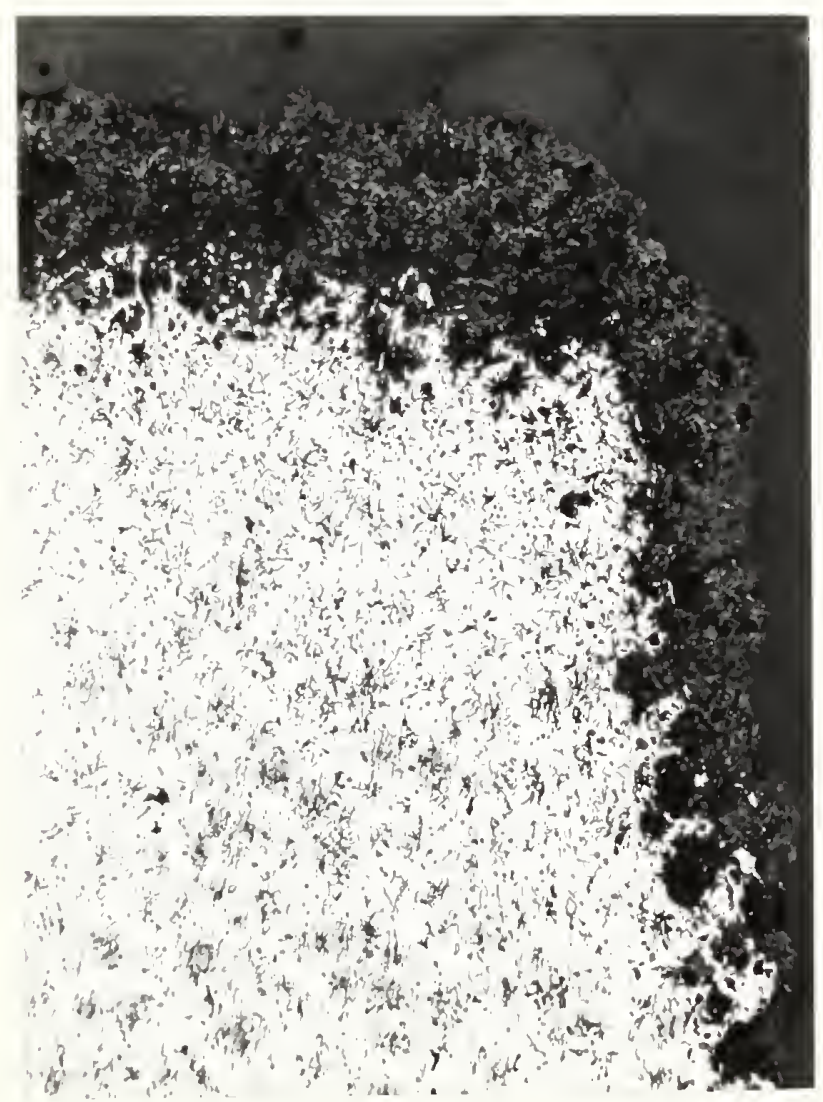

Figure 12. Longitudinal section F2 showing graphitization at the outside of the pipe (horizontal at the top) and along the fracture (vertical at the right). 


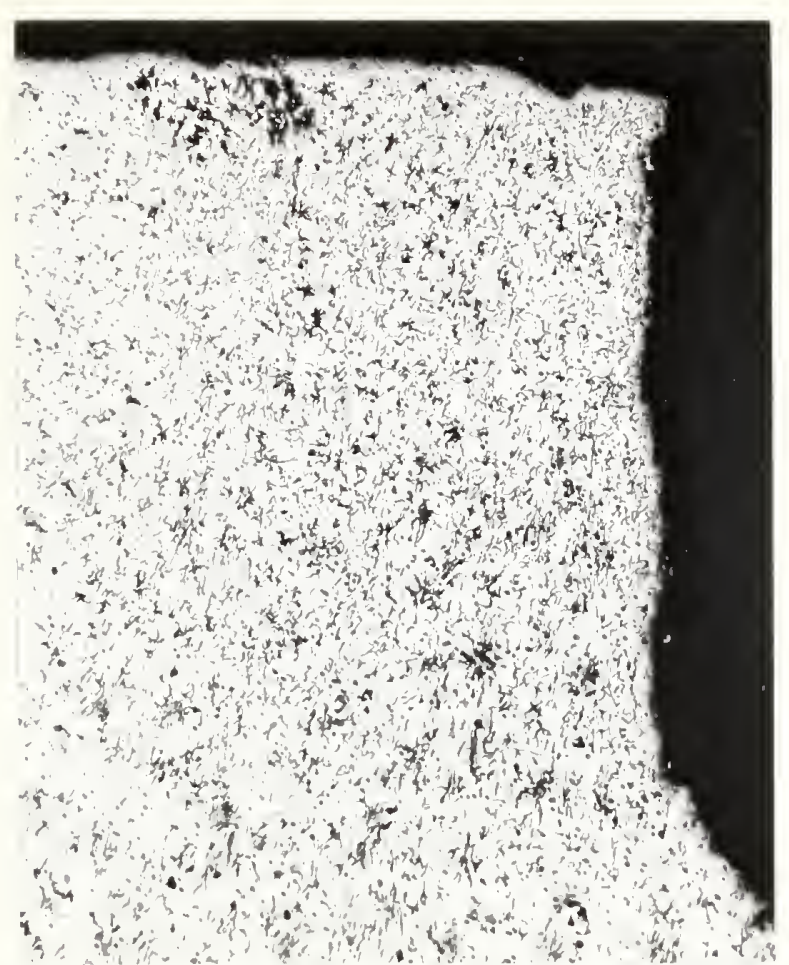

Figure 13. Longitudinal section $C$ showing the profile (vertical at the right) of the unusually flat region of the fracture near the outside of the pipe (horizontal at the top). As polished

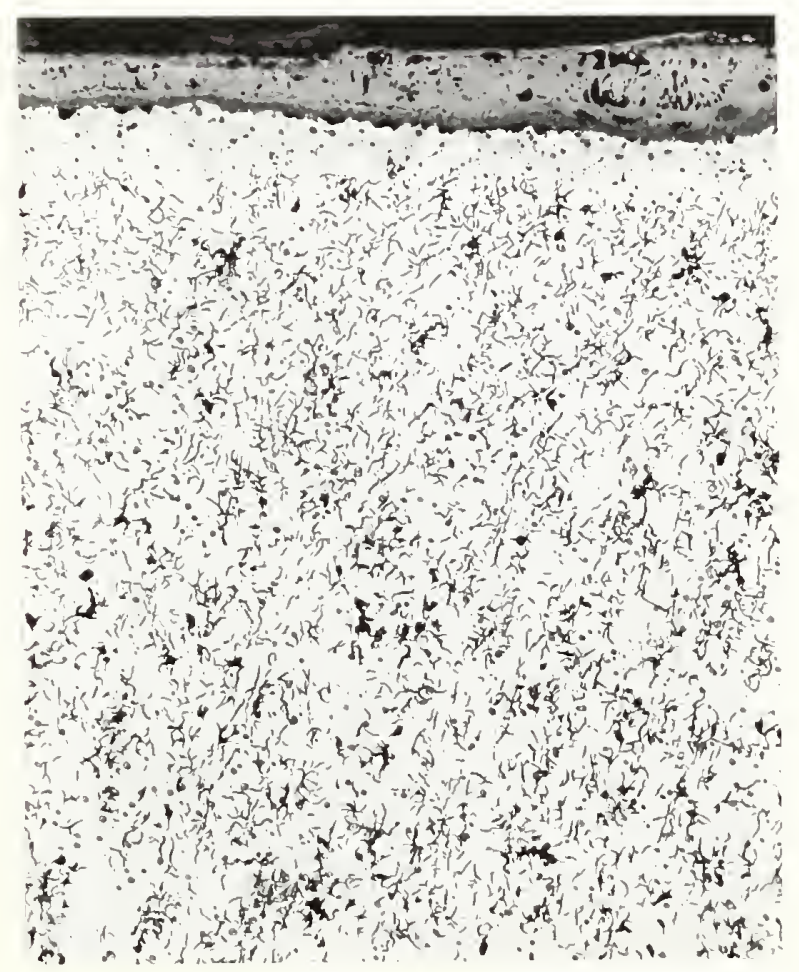

Figure 14. Longitudinal section D showing the representative unetched microstructure near the outside of the pipe. The graphite flakes are mostly type A. As polished 


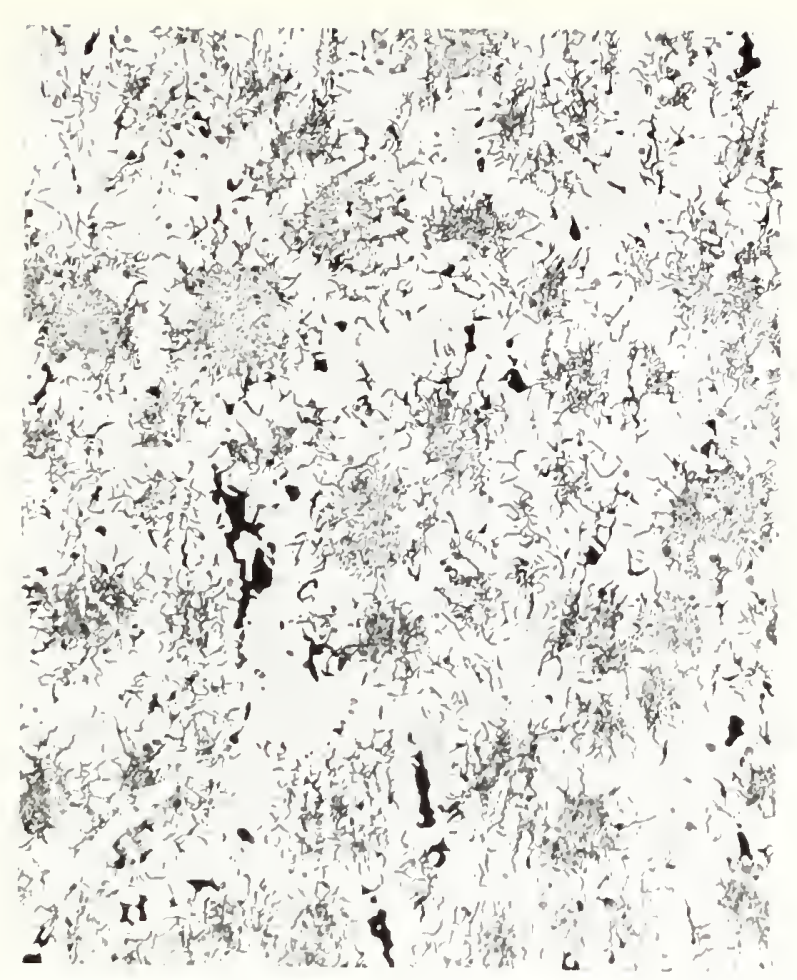

Figure 15. Longitudinal section D showing the representative unetched microstructure at the center of the pipe wall thickness. The graphite flakes are mostly type $B$ with some type $E$. As polished

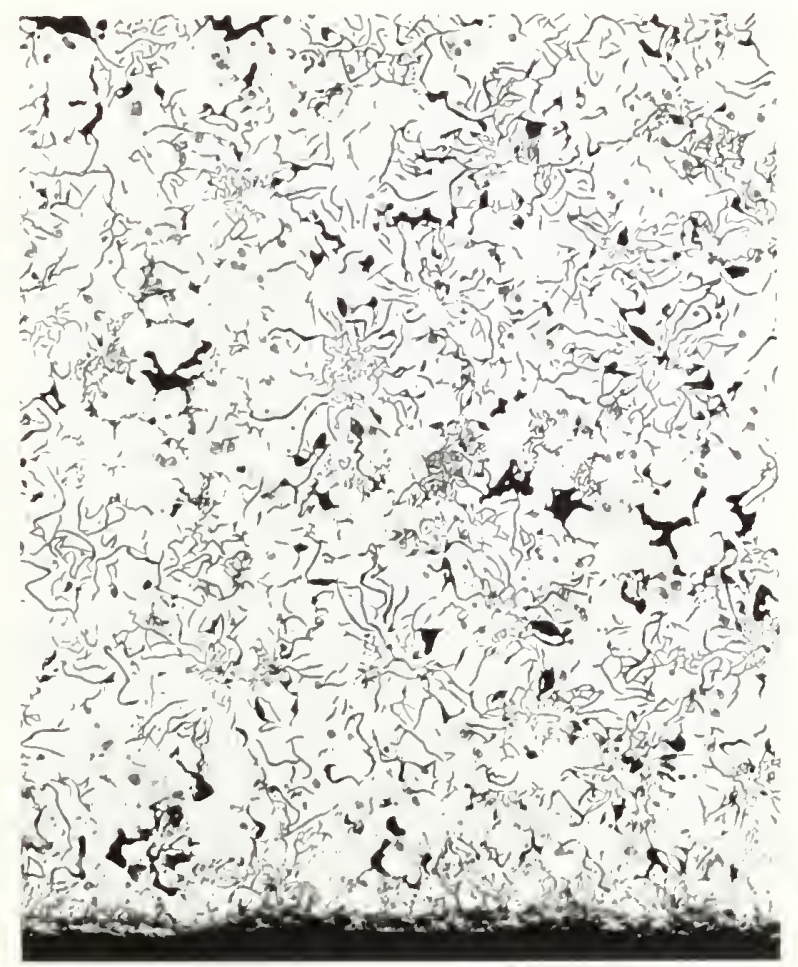

Figure 16. Longitudinal section D showing the representative unetched microstructure adjacent to the inside of the pipe. The graphite flakes are a mixture of types $A$ and $B$. As polished 


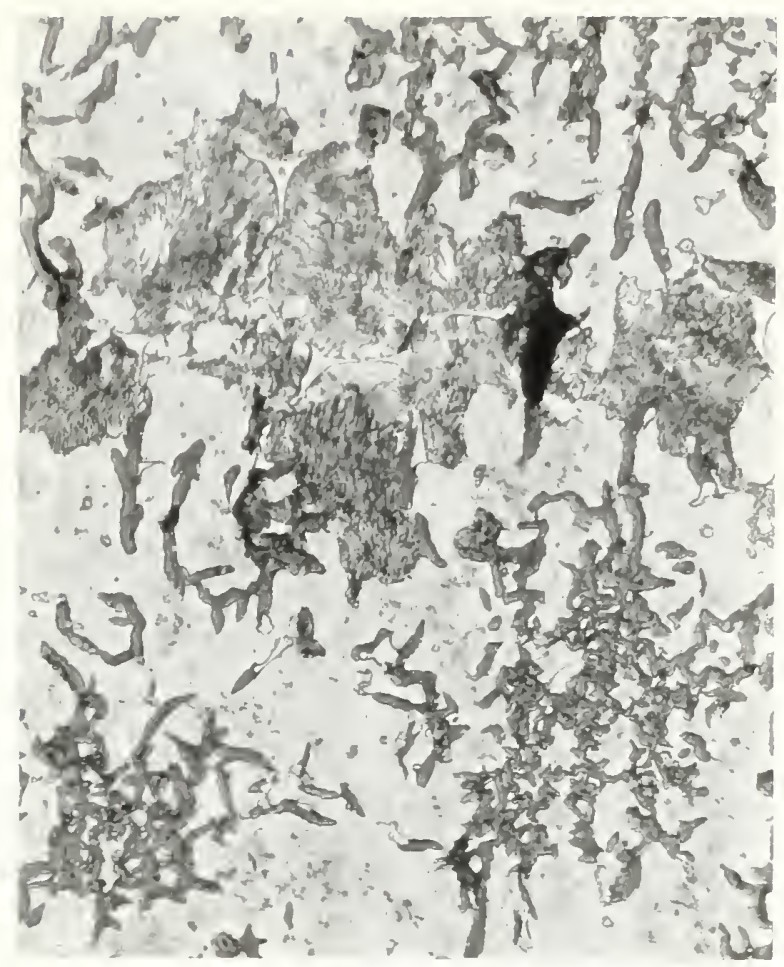

Figure 17. Longitudinal section D showing the representative etched microstructure near the center of the pipe wall. The microstructure consists primarily of graphite flakes, pearlite (fingerprint pattern), and ferrite (light colored phase). Etchant: 1\% nital

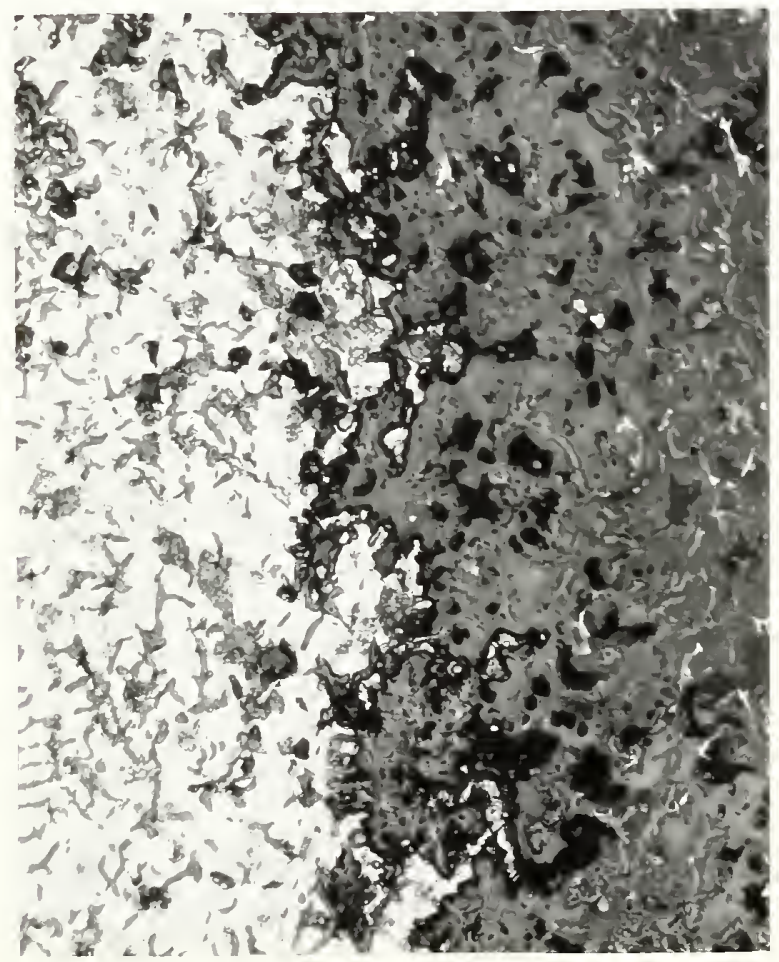

Figure 18. Longitudinal section E2 showing the etched microstructure adjacent to the fracture and the graphitization at the fracture. 


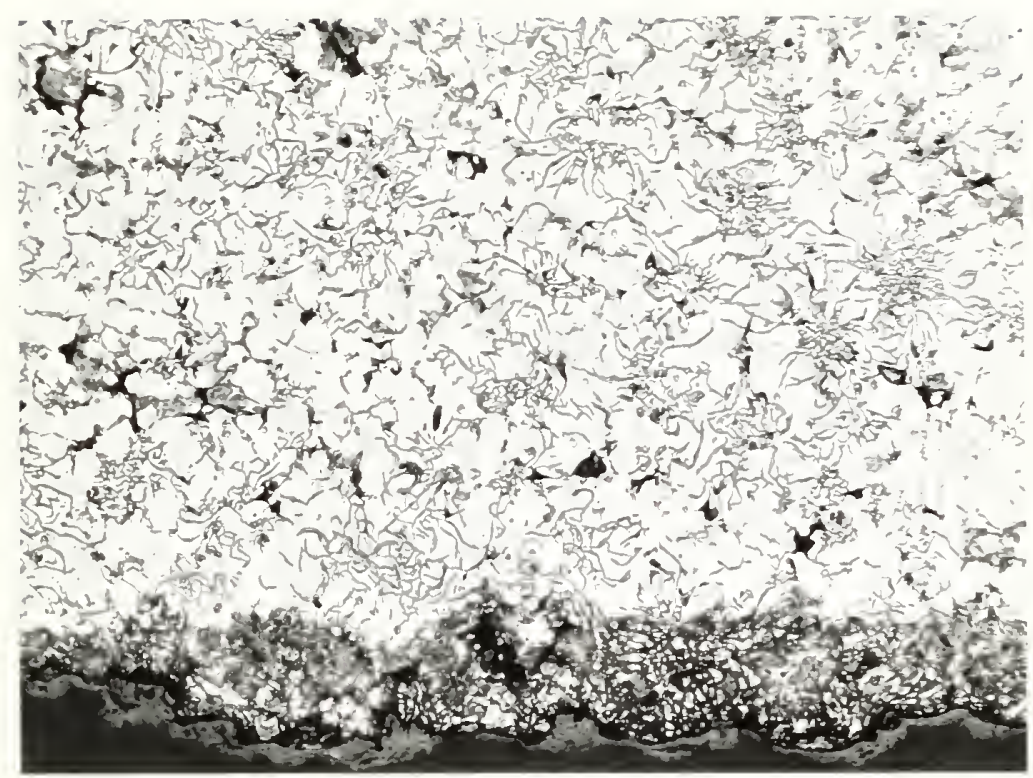

Figure 19. Longitudinal section F2 showing etched microstructure adjacent to the inside of the pipe (horizontal at the bottom). The layer of high pearlite concentration adjacent to the inside of the pipe is evident. Etchant: $1 \%$ nital X 100 
U.S. DEPT. OF COMIM.

BIBLIOGRAPHIC DATA

SHEET

TITLE AND SUBTITLE

EXANINATION OF FAILED FOUR INCH DIAMETER CAST IRON PIPE

NATURAL GAS MAIN, HAMDEN, CONNECTICUT
1. I'UIBLICATION OR REPORT NO.

NBSIR $78-1470$
2. Gov't Accession
No.

\section{AUTHOR(S)}

T. Robert Shives

PERFORMING ORGANIZATION NAME AND ADDRESS

\section{NATIONAL BUREAU OF STANDARDS \\ DEPARTMENT OF COMMERCE \\ WASHINGTON, D.C. 20234}

3. Recipient's Accession No.

5. Publication Date

Apri1 1978

6. Performing Organization Code

8. Performing Organ. Report No. NBSIR 78-1470

10. Project/Task/Work Unit No. 5620412

11. Contract/Grant No. Covered

Failure Analysis

14. Sponsoring Agency Code

Washington, D.C. 20594

\section{SUPPLEMENTARY NOTES}

ABSTRACT (A 200-word or less factual summary of most significant information. If document includes a significant bibliography or literature survey, mention it here.)

The submitted four inch diameter grey cast iron natural gas main pipe had failed due to a transverse fracture. Failure was probably caused by stresses from an external source. Loading was likely applied in bending. Although there were no fracture features to indicate the fracture origin, it appears likely that the top of the pipe was the last to fail.

Most of the corrosion product on the fracture surface appeared to be superficial. There was one region of significant graphitization at the fracture near the bottom of the pipe. At its deepest, the graphitization had penetrated about one half the pipe wall thickness.

The microstructure, hardness, and chemical composition of the pipe material appeared to be satisfactory. The material satisfied the Talbot test and ring test requirements of American National Standard A21.9, 1970.

KEY WORDS (six to twelve entries; alphabetical order; capitalize only the first letter of the first key word unless a proper name; separated by semicolons)

Brittle fracture; cast iron; cast iron pipe; graphitization.

AVAILABILITY Unlimited

[XXF or Official Distribution. Do Not Release to NTIS

Order From Sup. of Doc., U.S. Government Printing Office Washington, D.C. 20402, SD Cat. No.C13

Order From National Technical Information Service (NIIS) Springfield, Virginia 22151

\begin{tabular}{|l|l|}
\hline $\begin{array}{l}\text { 19. SECURITY CLASS } \\
\text { (THIS REPURT) }\end{array}$ & 21. NO. OF PAGES \\
UNCL ASSIFIED & \\
\hline $\begin{array}{l}\text { 20. SECURITY CLASS } \\
\text { (THIS PAGE) } \\
\text { UNCLASSIFIED }\end{array}$ & 22. Price \\
\hline
\end{tabular}


